\title{
Alcohols lower the threshold temperature for the maximal activation of a heat shock expression vector in the yeast Saccharomyces cerevisiae
}

\author{
Brendan P. G. Curran and S. A. Khalawan \\ Author for correspondence: Brendan P. G. Curran. Fax: +44 819830973.
}

School of Biological Sciences, Queen Mary and Westfield College, Mile End Road, London E1 4NS, UK

\begin{abstract}
When the yeast Saccharomyces cerevisiae is exposed to elevated growth temperatures, genes containing a heat shock element (HSE) in their promoters are activated. This study demonstrates that alcohols lower the temperature required for the maximal activation of such a promoter and that the concentration of alcohol required decreases as its hydrophobicity increases. A similar correlation has been found between the members of this alcohol series and their effect on a range of membrane functions. Our results therefore indicate that perturbation of the cell membrane may play a role in the heat induced activation of this HSE-containing promoter.
\end{abstract}

Keywords: Saccharomyces cerevisiae, heat shock response, heat shock element, cell membrane, alcohols

\section{INTRODUCTION}

All living cells examined to date produce an evolutionarily conserved group of proteins, the heat shock proteins, when they are exposed to a sudden, sublethal increase in their growth temperature. Some or all of these proteins are also induced when the cells are exposed to other stressing agents such as alcohol, heavy metals and anoxia (for reviews see Mager \& Ferreira, 1993; Lindquist, 1986). The presence of a short DNA sequence, the heat shock element (HSE), in the promoters of these genes determines the regulation of this expression (Pelham, 1982). A heat shock transcription factor (HSTF) can bind to a promoter containing a HSE and subsequently activate the gene (Sorger \& Pelham, 1988; Wiederrecht et al., $1988)$. In yeast, the level of heat shock gene activation is determined by the level of HSTF phosphorylation; increased phosphorylation induces increased gene expression (Sorger \& Pelham, 1988). However, the mechanism(s) responsible for transducing heat stress into an intracellular message resulting in HSTF phosphorylation, has (have) yet to be elucidated (for a review see Sorger, 1991).

The classical view of the heat shock response (HSR) is that stressing agents induce protein denaturation, with a resultant induction of the stress response. At the mol-

Abbreviations: HSE, heat shock element; HSR, heat shock response; HSTF heat shock transcription factor. ecular level, HSTF appears to be maintained in a repressed state in the absence of heat shock. It may be that heat stress causes negative regulatory proteins to dissociate from the HSTF, or heat stress may simply induce conformational changes in the HSTF itself (see Sorger, 1991). An alternative view is that the plasma membrane becomes leaky as a consequence of heat stress and that changes in intracellular $\mathrm{pH}$ may somehow be responsible for heat shock gene activation (Coote et al., 1991). These two models are not mutually exclusive because protein conformation is $\mathrm{pH}$ sensitive, but if heat stress is transduced into an intracellular signal at the level of the cell membrane, then molecules (such as alcohols) that interact with the membrane might be expected to alter the cell's HSR profile.

In this paper we demonstrate that the temperature for the maximal induction of a heat-shock-inducible expression vector decreases in the presence of alcohol, and that the concentration of alcohol required to achieve this effect is inversely related to the alcohol's hydrophobicity. These results implicate a perturbation of the cell membrane in the heat induced activation of this heat shock sensitive promoter and support the view that thermal stress may be transduced into a cellular signal at the level of the cell membrane.

\section{METHODS}

Strains. A haploid strain of Saccharomyces cerevisiae, DBY747 $M A T$ a leu2-112 lew2-3 ura3 his3 trp1), was transformed with the 
plasnid GA1659-HSE1 (a kind gift from Dr P. Sorger) by spheroplast transformation (Becker \& Guarente, 1991) and the resulting strain (DBY747-HSE1) was used in this study.

GA1659-HSE1 contains a HSE sequence upstream of a lac $Z$-cytochrome $c_{1}$ gene fusion construct. It also carries a wildtype copy of the ura3 gene. $\beta$-Galactosidase is not expressed at detectable levels in exponentially growing DBY747-HSE1 under normal growth conditions.

Culture conditions. DBY747-HSE1 was grown in minimal medium ( $\mathrm{w} / \mathrm{v}: 0.67 \%$ yeast nitrogen base, without amino acids, $2 \cdot 0 \%$ glucose) supplemented with histidine $\left(20 \mathrm{mg} \mathrm{l}^{-1}\right)$, leucine $\left(30 \mathrm{mg} \mathrm{l}^{-1}\right)$ and tryptophan $\left(20 \mathrm{mg} \mathrm{l}^{-1}\right)$. Cultures were grown overnight at $25^{\circ} \mathrm{C}$ in a shaking waterbath to mid-exponential phase $\left(2-3 \times 10^{6}\right.$ cells $\left.\mathrm{ml}^{-1}\right)$.

Stress procedure. Aliquots $(20 \mathrm{ml})$ of exponentially growing cells were placed in $250 \mathrm{ml}$ conical flasks and subjected to one of the following treatments: no addition; $6 \%(\mathrm{v} / \mathrm{v})$ methanol added; $2.6 \%(\mathrm{v} / \mathrm{v})$ ethanol added; $1.5 \%(\mathrm{v} / \mathrm{v}) n$-propanol added; $0.5 \%$-butanol added; $0.3 \%$ (v/v) $n$-pentanol added. The mouth and neck of each flask was covered with a sheet of clingfilm and secured with masking tape to prevent evaporation of alcohol. The flasks were placed in shaking waterbaths at the appropriate temperature for $1 \mathrm{~h}$.

Cells were harvested by spinning at 3000 r.p.m. for $3 \mathrm{~min}$ in an MSE bench-top centrifuge. The pellets were resuspended in $1 \mathrm{ml}$ ice-cold Z-buffer (Miller, 1972) (0.05 M sodium phosphate $\mathrm{pH} 7 \cdot 0,0 \cdot 01 \mathrm{M}$ potassium chloride, $1 \mathrm{mM}$ magnesium sulphate, $0.05 \mathrm{M} \beta$-mercaptoethanol) and transferred to $1.5 \mathrm{ml}$ Eppendorf tubes. These tubes were spun at 13000 r.p.m. in an MSE microfuge for $1.5 \mathrm{~min}$ and the supernatants discarded. Glass beads $(0.4 \mathrm{~mm}$; Sigma) equal in volume to the cell pellet, were added to the tubes and $20 \mu \mathrm{l} \mathrm{Z}$-buffer was also added. The cells were disrupted by whirlimixing the samples for $30 \mathrm{~s}$, on twelve occasions, and cooling them on ice for $1 \mathrm{~min}$ between each burst

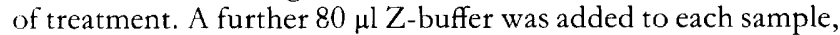
whirlimixed briefly and spun for $5 \mathrm{~s}$ at 13000 r.p.m. in an MSE microfuge. The $\beta$-galactosidase activity and protein concentration in the supernatants were measured.

$\beta$-Galactosidase assay. 0 -Nitrophenol $\beta$-D-galactopyranoside (ONPG) hydrolysis was used to monitor $\beta$-galactosidase activity: $20 \mu \mathrm{l}$ supernatant was added to a $1 \mathrm{ml}$ solution of $0.2 \mathrm{ml}$

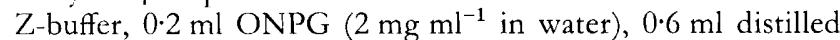
water and incubated for $30 \mathrm{~min}$ at $37^{\circ} \mathrm{C}$. Absorbance readings were taken at $430 \mathrm{~nm}$. The $\beta$-galactosidase activity was expressed in units defined as the change in absorption at $430 \mathrm{~nm}$ in $30 \mathrm{~min}$ $(\mathrm{mg} \text { protein })^{-1}$. Bio-Rad protein reagent was used according to the manufacturer's instructions to estimate the total protein content in the supernatants.

\section{RESULTS}

\section{The presence of alcohol lowers the temperature of maximal HSR}

In preliminary experiments (data not shown), the concentration of alcohol that produced a maximal heat shock response profile was established for each of five alcohols. These concentrations were then used in a comparative study on the effect of carbon-chain length on the heat shock response. The results of this study are presented in Fig. 1. In the interests of clarity the data are presented as two graphs.

In the absence of alcohol, exponentially growing cells showed low-level induction of $\beta$-galactosidase activity at $33^{\circ} \mathrm{C}$. This gradually increased until it peaked at $40^{\circ} \mathrm{C}$ before dropping rapidly, due to cell death, as the temperature increased to $43^{\circ} \mathrm{C}$.

In the presence of alcohol, exponentially growing cells had a 3-5-fold higher level of $\beta$-galactosidase induction at $33{ }^{\circ} \mathrm{C}$ than that found in untreated control cells. The level of induction gradually increased over the next $4^{\circ} \mathrm{C}$, peaking at $37^{\circ} \mathrm{C}$, before dropping rapidly, due to cell death, as the temperature increased further. Alcoholtreated cells showed a similar pattern of response, irrespective of carbon-chain length, with the maximum heat shock response occurring at $37^{\circ} \mathrm{C}$ in each case.

These results are consistent with alcohol and temperature having synergistic effects on the cell's HSR. They suggest that alcohols mediate a reduction in both the minimum and maximum temperatures required for the HSR in $S$. cerevisiae.

\section{The concentration of alcohol required to lower the threshold of maximum HSR decreases with increasing carbon-chain length}

A semi-log plot of the alcohol concentration required to produce a maximal HSR versus the number of carbons in the stressing alcohol, is presented in Fig. 2. It reveals a straight-line relationship between these two variables.

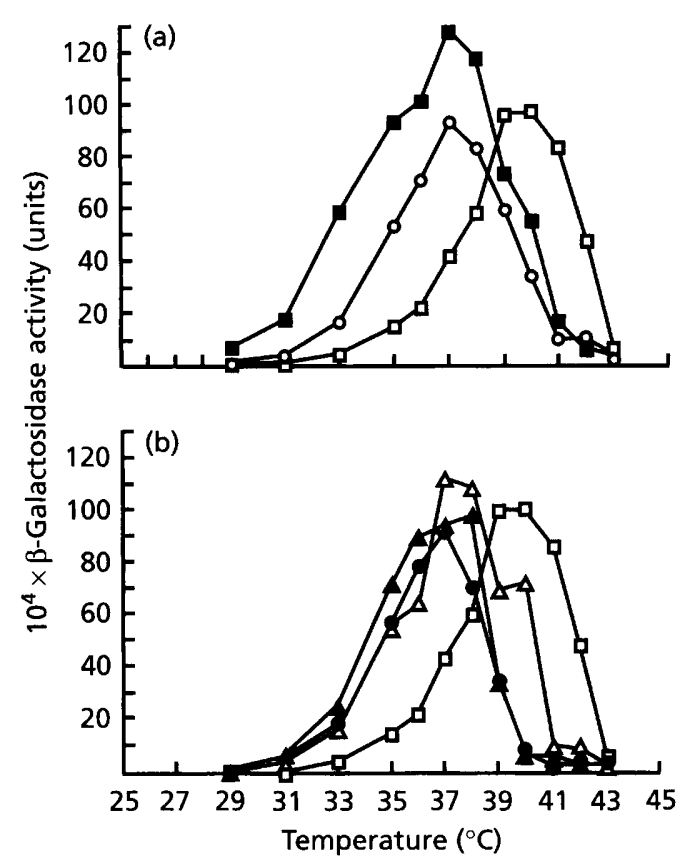

Fig. 1. Alcohols lower the temperature of maximal HSR. S. cerevisiae DBY747-HSE1 was grown overnight at $25^{\circ} \mathrm{C}$ and subjected to one of the following treatments. (a) No addition $(\square) ; 1.875 \mathrm{M}$ methanol added $(\square) ; 0.565 \mathrm{M}$ ethanol added $(O)$. (b) No addition ( $\square$ ); $0.233 \mathrm{M} \mathrm{n}$-propanol added (0); $0.068 \mathrm{M} \mathrm{n}$ butanol added $(\triangle) ; 0.034 \mathrm{M}$ n-pentanol added $(\boldsymbol{\Delta})$. Samples were incubated for $1 \mathrm{~h}$ at the indicated temperatures. (It was technically impossible to process replicate samples for this simultaneous comparisons of six treatments at twelve different temperatures but repeated experiments comparing individual alcohols and the control also revealed this shift.) 


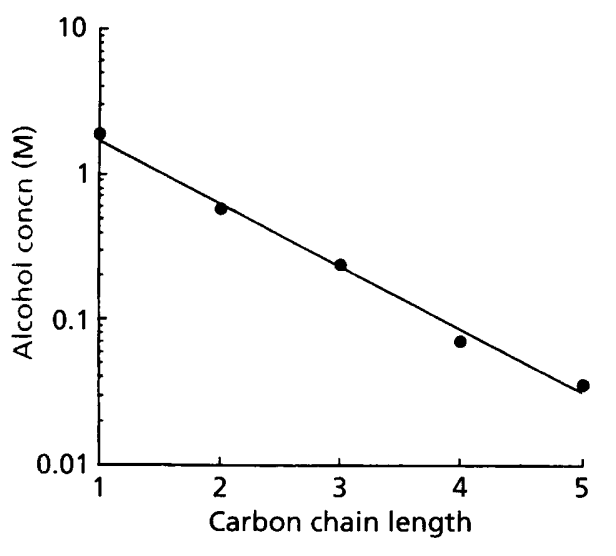

Fig. 2. The concentration of alcohol required to lower the threshold of maximal HSR decreases with increasing carbonchain length. The logarithm of the alcohol concentrations required to induce the maximum HSR was plotted against the number of carbons in the alcohols.

If membrane perturbation is involved in the HSR, agents that interact with the cell membrane should affect the response. The lipid: water partition coefficient of alcohols increases with increasing carbon-chain length (Katz \& Diamond, 1974). That a proportionally lower concentration of alcohol elicited the same shift in the maximum HSR threshold as the carbon-chain length increased, supports the hypothesis that the membrane plays a role in modulating the cell's response to an increase in temperature.

\section{DISCUSSION}

A large number of studies have been conducted on the physiological responses of microbial cells to the presence of alcohols (for reviews see O'Neal Ingram \& Buttke, 1984; Jones, 1989). Leǎo \& van Uden (1982) demonstrated that the concentration of alcohol required to kill yeast cells decreased as the carbon-chain length of the alcohol increased. Alcohol has also been shown to induce heat-shock-inducible genes in yeast in the absence of elevated temperatures (Plesset et al., 1982) and indeed Kirk \& Piper (1991) used high concentrations of methanol to induce high level expression from a heat-shockinducible expression vector in $S$. cerevisiae at its normal growth temperature of $25^{\circ} \mathrm{C}$.

This is the first paper to present a systematic examination of the effect that alcohol concentration and carbon-chain length have on the ability of yeast cells to mount a stress response in the face of elevated temperatures. It demonstrates that alcohol can lower the temperature required for the maximum induction of a heat-shock-inducible promoter in the yeast $S$. cerevisiae by $3{ }^{\circ} \mathrm{C}$ (Fig. 1) and that the concentration needed to achieve this decreases as alcohol hydrophobicity increases (Fig. 2). Similar correlations have been found between members of this alcohol series and their effect on a range of membrane functions, including spin label mobility in a liquid bilayer (Paterson et al., 1972), the ionic permeability of a synthetic lipid membrane (Gutknecht \& Tosteson, 1970) and the structural stability of erythrocyte membranes (Seeman, 1966). Furthermore, in the case of the spin label and ionic permeability papers, it was clearly shown that these alcohols had a profound effect on the structural organization of phospholipids.

The hydrophobic nature of the longer-chain alcohols ensures that they preferentially partition into the lipid bilayer of the cell, and the correlation depicted in Fig. 2 is typical of the type of result that implicates a hydrophobic action site in the physiological system under investigation (Thevelein et al., 1979). Our results therefore suggest that the lipid membrane plays a critical role in the physiology of the cell's heat shock response. The yeast cell membrane is much more complex than the synthetic bilayers used in the spin label mobility and ionic permeability studies mentioned above and the membrane-alcohol interaction is therefore difficult to interpret unequivocally. This study does not seek to elucidate the precise molecular target involved but rather to lend support to a model for the heat shock response in which environmental stress is transduced into a cellular signal at the level of the cell membrane.

Yeast cell membranes contain a $100 \mathrm{kDa}$ ATPase protein that maintains a transmembrane electrochemical gradient by pumping $\mathrm{H}^{+}$ions out of the cells (Serrano 1988; Ulaszewski et al., 1983). The activity of this $\mathrm{H}^{+}$-ATPase influences the resistance of yeast cells to a variety of stresses (including heat shock) (Panaretou \& Piper, 1990; Coote et al., 1991), and Coote et al. (1991) have demonstrated that heat stress causes a partial dissipation of the $\mathrm{H}^{+}$gradient that exists across the cell membrane. It is possible that the presence of alcohol in the medium allows this dissipation to occur at a temperature lower than that at which it normally occurs, with the subsequent activation of the stress response genes. Future experiments should reveal if this is indeed the case.

\section{ACKNOWLEDGEMENTS}

B. P. G. Curran gratefully acknowledges support from the SGM research fund. We thank Dr V. Bugeja for helpful discussions, and J. Smith and G. Cohen for preparing the manuscript.

\section{REFERENCES}

Becker, D. M. \& Guarente, L. (1991). High efficiency transformation of yeast by electroporation. Methods in Enzymol 194, 186-187.

Coote, P. J., Cole, M. C. \& Jones, M. V. (1991). Induction of increased thermotolerance in Saccharomyces cerevisiae may be triggered by a mechanism involving intracellular $\mathrm{pH}$. J Gen Microbiol 137, 1701-1708.

Gutknecht, J. \& Tosteson, D. C. (1970). Ionic permeability of thin lipid membranes. Effects of n-alkyl alcohols, polyvalent cations and a secondary amine. J Gen Physiol 55, 359-374.

Jones, R. P. (1989). Biological principles for the effects of ethanol. Envyme Microb Tecbnol 11, 130-153.

Katz, Y. \& Diamond, J. M. (1974). Thermodynamic constants for 
non-electrolyte partition between dimyristoly lecithin and water. $J$ Membr Biol 17, 101-120.

Kirk, N. \& Piper, P. W. (1991). Methanol as a convenient inducer of heat shock element-directed heterologous gene expression in Sacharomyces cerevisiae. Biotechnol Lett 13, 465-470.

Leăo, C. \& van Uden, N. (1982). Effects of ethanol and other alkanols on the kinetics and the activation parameters of thermal death in Saccharomyces cerevisiae. Biotechnol Bioeng 24, 1581-1590.

Lindquist, S. (1986). The heat shock response. Annu Rev Biochem 55, 1151-1191.

Mager, W. H. \& Ferreira, P. M. (1993). Stress response of yeast. Biochem J 290, 1-13.

Miller, J. H. (1972). Experiments in Molecular Genetics. Cold Spring Harbor, NY: Cold Spring Harbor Laboratory.

O'Neal Ingram, L. \& Buttke, T. M. (1984). Effects of alcohols on micro-organisms. Adv Microb Physiol 25, 254-300.

Panaretou, B. \& Piper, P. W. (1990). Plasma-membrane ATPase action affects several stress tolerances of Saccharomyces cerevisiae and Schizosaccharomyces pombe as well as the extent and duration of the heat shock response. J Gen Microbiol 136, 1763-1770.

Paterson, S. J., Butler, K. W., Huang, P., Labelle, J., Smith, I. C. P. \& Schneider, H. (1972). The effects of alcohols on lipid bilayers: spin label study. Biochim Biophys Acta 266, 597-602.

Pelham, H. R. B. (1982). A regulatory upstream promoter element in the Drosophila HSP70 heat-shock gene. Cell 30, 517-528.

Plesset, J., Palm, C. \& McLaughlin, C. S. (1982). Induction of heat shock protein and thermotolerance by ethanol in Saccbaromyces cerevisiae. Biochem Biophys Res Commun 108, 1340-1345.

Seeman, P. (1966). Erythrocyte membrane stabilization by steroids and alcohols: a possible model for anesthesia. Biochem Pharmacol 15, 1632-1637.

Serrano, R. (1988). Structure and function of proton translocating ATPase in plasma membranes of plants and fungi. Biochim Biophys Acta 947, 1-28.

Sorger, P. K. (1991). Heat shock factor and the heat shock response. Cell 65, 363-366.

Sorger, P. K. \& Pelham, H. R. B. (1988). Yeast heat shock factor is an essential DNA-binding protein that exhibits temperaturedependent phosphorylation. Cell 54, 855-864.

Thevelein, J. M., van Assche, J. A., Carlier, A. R. \& Heremans, K. (1979). Heat activation of Phycomyces blakesleeanus spores: thermodynamics and effects of alcohols, furfural and high pressure. $J$ Bacteriol 139, 478-485.

Ulaszewski, S., Grenson, M. \& Goffeau, A. (1983). Modified plasma-membrane ATPase in mutants of Saccharomyces cerevisiae. Eur J Biochem 130, 235-239.

Wiederrecht, G., Seto, D. \& Parker, C. S. (1988). Isolation of the gene encoding the $S$. cerevisiae heat shock transcription factor. Cell $54,841-853$.

Received 8 December 1993; revised 15 March 1994; accepted 12 April 1994. 